https://doi.org/10.52058/2708-7530-2021-2(8)-234-243

Романенко Свген Олександрович доктор наук з державного управління, професор, Заслужений юрист України, Президент Всеукраїнської асамблеї докторів наук 3 державного управління, Проректор, Міжрегіональна Академія управління персоналом, вул. Фрометівська, 2, м. Київ, 03039, тел.: (044) 264-5254, e-mail: poboss1978@gmail.com, https://orcid.org/0000-0003-2285-0543.

Непомнящий Олександр Михайлович доктор наук 3 державного управління, професор, Заслужений будівельник України, Президент Міждержавної гільдії інженерів-консультантів, професор кафедри публічного адміністрування, Міжрегіональна академія управління персоналом, вул. Фрометівська, 2, м. Київ, 03039, тел.: (044) 264-52-54, e-mail: n_a_m@ukr.net, https://orcid.org/0000-0002-5766-3150.

\title{
ВЕРХОВНА РАДА ЗРОБИЛА ДРУГУ СПРОБУ УЗАКОНИТИ ПРИВАТНУ ДЕТЕКТИВНУ ДІЯЛЬНІСТЬ
}

Анотація. Визначено, що у більшості країн світу приватна детективна діяльність визнана на державному рівні, врегульована законами й оптимально використовується задля збільшення можливості громадян та юридичних осіб у захисті своїх законних прав та інтересів. Сполучені Штати Америки, Великобританія, Франція, Німеччина, Канада, Індія, Ізраїль, Японія, Норвегія, Іспанія, Італія, Португалія, Мексика, Російська Федерація та багато інших країн світу являють собою ті регіони планети, де запровадження інститутів приватних детективів, приватних детективних підприємств (агентств) та їх об'єднань стало у свій час наслідком реагування влади на нагальні соціальні виклики.

Доведено, що приватні детективи та приватні детективні підприємства (агентства) надають суттєву допомогу суб'єктам підприємницької діяльності у вивченні репутації та фінансового стану позичальників та інших партнерів, визначенні їх спроможності реально виконувати взяті на себе фінансові зобов'язання, що у значній мірі запобігає укладенню ризикованих угод та ухиленню боржників від сплати заборгованості.

Зазначено, що професійна підготовка приватних детективів в Україні здійснюється на рівні вищої освіти у декількох закладах вищої освіти, а проблеми, пов'язані з пробілом у національному законодавстві щодо унормування приватної детективної діяльності в Україні є предметом досліджень численних науково - 
експертних досліджень.

Обгрунтовано, що становлення та функціонування в Україні ринку приватних детективних послуг $\epsilon$ соціально визнаним, а фактична приватна детективна практика захисту особистих та майнових прав фізичних осіб та юридичних осіб - суб'єктів приватного права потребує законодавчого унормування та подальшої розбудови нормативної та учбово-методичної основи iii запровадження, професійного опанування, легального практичного здійснення та суспільного контролю за нею.

Ключові слова: детективні послуги, суб'єкти підприємницької діяльності, Верховна Рада України, Асоціація Детективів.

Romanenko Yevhen Oleksandrovych Doctor of Science in Public Administration, Professor, Honored Lawyer of Ukraine, President of the Ukrainian Assembly of Doctors of Science in Public Administration, Vice-Rector, Interregional Academy of Personnel Management, Frometivska St., 2, Kyiv, 03039, tel.: (044) 26452-54, e-mail: poboss1978@gmail.com, https://orcid.org/0000-0003-2285-0543.

Nepomnyashchyy Oleksandr Mykhailovych Doctor of Science in Public Administration, Professor, Merited Builder of Ukraine, President of the Interstate Consultants Engineers Guild, Professor at the Department of Public Administration, Interregional Academy of Personnel Management, Frometivska St., 2, Kyiv, 03039, tel.: (044) 264-52-54, e-mail: n_a_m@ukr.net, https://orcid.org/0000-0002-5766-3150.

\section{THE VERKHOVNA RADA MADE A SECOND ATTEMPT TO LEGALIZE PRIVATE DETECTIVE ACTIVITY}

Abstract. It is determined that in most countries of the world private detective activity is recognized at the state level, regulated by law and is optimally used to increase the ability of citizens and legal entities to protect their legal rights and interests. The United States, Great Britain, France, Germany, Canada, India, Israel, Japan, Norway, Spain, Italy, Portugal, Mexico, the Russian Federation and many other countries are the regions of the world where the introduction of private detectives, private detective companies (agencies) and their associations were at one time the result of the government's response to urgent social challenges.

It is proved that private detectives and private detective companies (agencies) provide significant assistance to business entities in studying the reputation and financial condition of borrowers and other partners, determining their ability to actually fulfill financial obligations, which largely prevents the conclusion risky transactions and evasion of debtors from debt payment. 
It is noted that the professional training of private detectives in Ukraine is carried out at the level of higher education in several higher education institutions, and the problems related to the gap in the national legislation on standardization of private detective activity in Ukraine are the subject of numerous scientific studies.

It is substantiated that the formation and functioning of the market of private detective services in Ukraine is socially recognized, and the actual private detective practice of protection of personal and property rights of individuals and legal entities subjects of private law requires legislative regulation and further development of regulatory and educational basis. introduction, professional mastery, legal practical implementation and public control over it.

Keywords: detective services, business entities, the Verkhovna Rada of Ukraine, the Association of Detectives.

Постановка проблеми. Приватна детективна діяльність є сталою практикою захисту законних прав та інтересів громадян та юридичних осіб приватного права у країнах з розвинутою економікою, у тому числі на європейському континенті. Першу спробу легалізувати приватних детективів Верховна Рада зробила в квітні 2017 р. 28.12.2015p. у Верховній Раді було зареєстровано проекту Закону України № 3726 «Про приватну детективну (розшукову) діяльність».[1] 19.04.2016 р. він був прийнятий в першому читанні, а 13.04 .2017 р. був прийняти в другому читанні та в цілому. За прийняття в цілому законопроект № 3726 тоді проголосував 261 депутат. 06.06.2017 р. закон був повернутий у Верховну Раду 3 пропозиціями Президента. 18.12.2018 р. Вето Президента не подолано - закон відхилено.

Аналіз останніх досліджень та публікацій. У вітчизняній науці державного управління досліджуване питання підіймалося у наукових працях лише побіжно, без глибинного аналізу його нормативно-правового підгрунття.

Мета статті. Метою цієї статті є висвітлення особливостей становлення та функціонування в Україні ринку приватних детективних послуг.

Виклад основного матеріалу. У більшості країн світу приватна детективна діяльність визнана на державному рівні, врегульована законами й оптимально використовується задля збільшення можливості громадян та юридичних осіб у захисті своїх законних прав та інтересів. Сполучені Штати Америки, Великобританія, Франція, Німеччина, Канада, Індія, Ізраїль, Японія, Норвегія, Іспанія, Італія, Португалія, Мексика, Російська Федерація та багато інших країн світу являють собою ті регіони планети, де запровадження інститутів приватних детективів, приватних детективних підприємств (агентств) та їх об’єднань стало у свій час наслідком реагування влади на нагальні соціальні виклики, і тому на сьогодні, існування та діяльність таких недержавних інституцій є у них явищем 
звичайним, усталеним і достатньо унормованим національним законодавством.

В Англії, наприклад, чисельність персоналу приватних охоронних й детективних фірм вдвічі перевищує кількість співробітників поліції. У США приватні служби безпеки мають бюджет, який на 50\% перевищує бюджет усіх органів поліції країни разом узятих, і нараховують понад 1,1 млн. співробітників. В державі Ізраїль (з населенням трохи більше 5 млн. чоловік) функціонує понад двох тисяч детективних і охоронних компаній.

Попри це, цивілізаційні потреби сучасного суспільства спонукають до пошуків шляхів удосконалення організаційної системи, структури i функції національних суб’єктів приватної детективної діяльності, у тому числі і через використання новітніх детективних технологій та передового досвіду приватної детективної діяльності інших країн, що визнаються й сприймаються Всесвітньою Асоціацією Детективів.

Заснована ще в 1925 році найбільш цивілізованими країнами Всесвітня Асоціація Детективів - найавторитетніша міжнародна організація у сфері розслідувань та безпеки. Вона об’єднує на сьогодні понад однієї тисячі кращих спеціалістів приватних детективних і охоронних структур із більш ніж 60 країн світу, причому вони постійно розширюються, оскільки в ході кожної щорічної конференції, особливо в останні роки, на вступ до неї надходить до ста заявок.

Досвід країн, у яких приватна детективна діяльність законодавчо врегульована, показує, що функціонування приватних детективів, детективних підприємств (агентств) та їх об’єднань значно підвищує відповідальність державної правоохоронної системи за своєчасне і високопрофесійне реагування на потреби громадян і суспільства, звільняє правоохоронців від необхідності виконання багатьох незначних та невластивих їм функцій, сприяє загальному оздоровленню криміногенної ситуації.

Так, приватні детективи та приватні детективні підприємства (агентства) надають суттєву допомогу суб'єктам підприємницької діяльності у вивченні репутації та фінансового стану позичальників та інших партнерів, визначенні їх спроможності реально виконувати взяті на себе фінансові зобов'язання, що у значній мірі запобігає укладенню ризикованих угод та ухиленню боржників від сплати заборгованості.

Крім того, суб’єкти приватної детективної (розшукової) діяльності проводять велику роботу по пошуку осіб, місце знаходження яких не відоме, розшуку зниклого майна і тварин, виявленню фактів порушень прав інтелектуальної власності, насамперед незаконного використання товарних знаків та інше.[1]

В Україні на сьогодні такий вид діяльності офіційно не визнаний, а тому і не знайшов поки що свого законодавчого врегулювання, хоча фактично приватною детективною (розшуковою) діяльністю давно та плідно займаються не тільки 
фізичні особи, а й юридичні. За неофіційними даними, зараз в усіх регіонах України працює декілька тисяч приватних детективів та приватних детективних агентств.

Разом 3 тим, як нормативно визначений підвид економічної діяльності, ця діяльність зазначена у класі 80.30 «Проведення розслідувань» Розділу 80 «Діяльність охоронних служб та проведення розслідувань» за КВЕД - 2010, а кваліфікаційні вимоги до працівників у галузі надання детективних послуг затвердженні за кодом 5169 «Працівники захисних та охоронних служб» Національного класифікатора України. Класифікатор професій ДК 003:2005.

Діяльність 3 проведення розслідувань включена до числа профільних статутних завдань значної кількості недержавних охоронно - розшукових підприємств та агенцій практично в усіх регіонах України. Крім того, фактично означена діяльність має місце у провадженнях офіційно чинних інформаційних агентств, у зв'язку із журналістськими розслідуваннями та законодавчо не унормованій приватній діяльності декількох тисяч самозайнятих осіб підприємців.

Професійна підготовка приватних детективів в Україні здійснюється на рівні вищої освіти у декількох закладах вищої освіти, а проблеми, пов'язані з пробілом у національному законодавстві щодо унормування приватної детективної діяльності в Україні є предметом досліджень численних науково - експертних досліджень.[2]

Верховна Рада на засіданні 17 лютого 2021р. в першому читанні і за основу прийняла законопроект №3010 «Про приватну детективну діяльність».[2] Проект Закону складається з 22 статей, що об'єднані у V розділів, які, окрім загальних, прикінцевих та перехідних положень, визначають та регламентують:

- сферу приватної детективної діяльності, у тому числі види детективних послуг та суб’єктів їх провадження (надання);

- кваліфікаційні вимоги до приватних детективів;

- основні права та обов'язки суб'єктів приватної детективної діяльності, у тому числі правові механізми захисту інтересів замовників детективних послуг;

- обов'язки суб'єкта приватної детективної діяльності з обліку наданих детективних послуг, зберігання конфіденційної інформації, захисту персональних даних, отриманих у процесі надання детективних послуг;

- організація державного та громадського контролю за приватною детективною діяльністю.

Приватним детективом може бути фізична особа, яка має громадянство України, повну вищу юридичну освіту або вищу освіту за спеціальністю «правоохоронна діяльність», володіє державною мовою, стаж роботи в галузі права або правоохоронної діяльності 3 роки, пройшла відповідне навчання 3 238 
метою зайняття приватною детективною діяльністю та отримала свідоцтво про право на заняття приватною детективною діяльністю.

Не може бути приватним детективом особа, яка:

1) має непогашену чи не зняту в установленому законом порядку судимість за вчинення кримінального правопорушення;

2) визнана судом недієздатною чи обмежено дієздатною;

3) перебуває на обліку в психоневрологічних або наркологічних установах охорони здоров'я;

4) позбавлена права на зайняття приватною детективною діяльністю, протягом двох років 3 дня прийняття рішення Уповноваженим органом регулювання про припинення права на зайняття приватною детективною діяльністю.

3. Несумісною з діяльністю приватного детектива $є$ :

1) робота на посадах осіб, зазначених у пункті 1 та підпункті а) пункту 2 частини першої статті 3 Закону України «Про запобігання корупції» (за виключенням депутатів місцевих рад);

2) військова або альтернативна (невійськова) служба;

3) нотаріальна діяльність;

4) судово-експертна діяльність.

Приватний детектив, який здійснює приватну детективну діяльність індивідуально, є самозайнятою особою та може відкривати рахунки в банках, мати печатку, штампи, із зазначенням свого прізвища, імені та по батькові, номера і дати видачі свідоцтва про право на заняття приватною детективною діяльністю.

Детективне агентство $\epsilon$ юридичною особою, створеною у формі господарського товариства, одним 3 засновників (учасників) якого $є$ приватний детектив та діє на підставі статуту. Загальний розмір частки засновників (учасників) детективного агентства, які не $є$ приватними детективами, у статутному капіталі не може перевищувати 25\%.

Свідоцтво про право на зайняття приватною детективною діяльністю видаватиметься безстроково на платній основі (разова плата в розмірі одного прожиткового мінімуму для працездатних осіб на 1 січня поточного календарного року).

Договір про надання приватних детективних послуг можна буде укладати у письмовій або у електронній формі.

Приватні детективні послуги, які здійснюються на підставі договору про надання приватних детективних послуг, укладеного між замовником та суб'єктом приватної детективної діяльності шляхом пошуку, отримання, аналізу та фіксації інформації про осіб, об'єкти і події, встановлення місцезнаходження осіб та 
об'єктів із застосуванням засобів та методів, що не заборонені чинним законодавством України, можуть включати в себе, зокрема, наступні види детективних послуг:

1) збирання, фіксування та дослідження відомостей, необхідних для розгляду справ у кримінальному, цивільному, господарському, адміністративному судочинстві. Замовником цього виду послуг може бути лише сторона відповідного провадження;

2) вивчення ринку, пошук і збір інформації з відкритих джерел 3 метою підготовки ділових переговорів замовника, з'ясування фінансової платоспроможності, майнового стану та благонадійності потенційних ділових партнерів;

3) з'ясування біографічних та інших даних, що характеризують особу, стосовно окремих громадян (за їхньої письмової згоди) при укладенні ними трудових та інших договорів із замовником приватних детективних послуг (зайняття в нього відповідної вакантної посади), виявлення їхніх ділових зв’язків, у тому числі з конкурентами замовника, в Україні та за кордоном;

4) пошук осіб, місцезнаходження яких невідоме, з'ясування причин та обставин їх зникнення, можливостей i умов їх повернення, розшук осіб, які втратили родинні або дружні зв’язки;

5) спостереження за поведінкою неповнолітніх, недієздатних, обмежено дієздатних або осіб з інвалідністю на замовлення їх законних представників.

6) розшук зниклого (втраченого або викраденого) майна, предметів і тварин;

7) здійснення заходів з відтворення втраченої (зниклої) інформації з питань законних прав та інтересів замовника;

8) виявлення фактів незаконного (несанкціонованого) збирання інформації 3 метою використання відомостей, що становлять комерційну таємницю замовника, або їх розголошення, а також фактів незаконного (несанкціонованого) збирання конфіденційної інформації стосовно фізичних осіб;

9) пошук, виявлення та фіксування фактів незаконного використання прав інтелектуальної власності, що належать замовнику, а також випадків недобросовісної конкуренції;

10) пошук боржників та осіб, які ухиляються від виконання своїх договірних зобов’язань, а також належного їм майна та інших активів.

11) забезпечення захисту інформації з обмеженим доступом (комерційної, професійної таємниці) замовника приватних детективних послуг.

12) перевірка достовірності наданої страхувальниками страховим компаніям інформації про обставини заявлених страхових випадків;

13) збір інформації яка може бути підставою для звернення замовника приватних детективних послуг до уповноважених органів виконавчої та/або 
судової влади з метою захисту його законних прав і інтересів.

14) консультування 3 надання приватних детективних послуг.

Суб'єкти приватної детективної діяльності можуть надавати інші детективні послуги, не заборонені законом.

Суб’єкти приватної детективної діяльності під час здійснення такої діяльності мають право вчиняти будь-які дії, не заборонені законом, необхідні для належного виконання договору про надання приватних детективних послуг, зокрема, розшукувати, отримувати та накопичувати потрібну інформацію всіма не забороненими законом методами, у тому числі:

1) звертатися із запитами до органів державної влади, органів місцевого самоврядування, їх посадових i службових осіб, підприємств, установ, організацій, громадських об’єднань, а також до фізичних осіб;

2) за згодою підприємств, установ, організацій у визначеному обсязі ознайомлюватися на підприємствах, в установах, організаціях 3 необхідними для здійснення приватної детективної діяльності документами та матеріалами, крім тих, що містять інформацію з обмеженим доступом;

3) проводити зовнішній огляд територій, споруд, приміщень, інших об’єктів, доступ до яких не обмежений.

4) проводити зовнішній та внутрішній огляд закритих для вільного доступу територій, споруд, приміщень, інших об'єктів за згодою їх власників або законних користувачів.

5) проводити огляд та вивчення матеріалів, предметів, документів за згодою їх власників або законних користувачів;

6) отримувати на договірній основі письмові висновки та усні консультації фахівців та експертів з питань, що потребують спеціальних знань;

7) здійснювати спостереження на відкритій місцевості, у громадських місцях та на транспорті з метою отримання необхідної інформації;

8) здійснювати на відкритій місцевості та в громадських місцях, а у службових та приватних приміщеннях за письмовою згодою власників (або уповноважених ними осіб) під час відвідування приватним детективом цих приміщень, фотозйомку, відео- та аудіо запис, а також застосовувати інші технічні засоби фіксації інформації загального призначення, які не спричиняють шкоду життю та здоров’ю громадян, навколишньому середовищу;

9) проводити усне опитування осіб за їх згодою.

Письмовий запит суб’єкта приватної детективної діяльності, направлений під час надання приватних детективних послуг, є обов'язковим для розгляду в порядку, встановленому законодавством України про інформацію.

Особи, винні в ненаданні відповіді та /або наявної інформації, крім тієї що має конфіденційний характер, або наданні неповної та/або недостовірної 
інформації, несуть відповідальність встановлену законом.

За умисне розголошення детективної таємниці передбачено кримінальну відповідальність - штраф до 50 НМДГ (850 грн) або громадські роботи на строк до 240 годин, або позбавленням права обіймати певні посади чи займатися певною діяльністю на строк до трьох років, або виправними роботами на строк до двох років.[2]

Висновки. Отже, цілком очевидно, що становлення та функціонування в Україні ринку приватних детективних послуг є соціально визнаним, а фактична приватна детективна практика захисту особистих та майнових прав фізичних осіб та юридичних осіб - суб'єктів приватного права потребує законодавчого унормування та подальшої розбудови нормативної та учбово-методичної основи iï запровадження, професійного опанування, легального практичного здійснення та суспільного контролю за нею.[3] Розробка та прийняття Закону України «Про приватну детективну діяльність» дозволить на законодавчому рівні поставити такий вид діяльності під належний контроль держави, що відповідатиме сучасним тенденціям трансформації владних інституцій [4]. Україна ще раз підтвердить свою прихильність європейському курсу та безумовно підвищить імідж, як правової держави серед цивілізованих країн світу.

\section{Лimepamypa:}

1. Про приватну детективну (розшукову) діяльність: проекту Закону України від 28.12.2015p № 3726.Режим доступу: http://w1.c1.rada.gov.ua/pls/zweb2/webproc4_1?pf3511= 57580

2. Про приватну детективну діяльність: проект Закону України від 04.02.2020 № 3010 . Режим доступу: http://w1.c1.rada.gov.ua/pls/zweb2/webproc4_1?pf3511=68051

3. Романенко Є. О., Чаплай I. В. Забезпечення розбудови громадянського потенціалу в Україні//Експерт: парадигми юридичних наук і державного управління: електронне наукове видання: збірник. - 2018. - № 2 (2) - грудень. - Київ : ДП “Видавничий дім "Персонал”, 2018. - с. 87-93.

4. Дегтяр О.А., Непомнящий О.М. Трансформація в умовах глобалізації функцій інституту держави, громадянського суспільства та їх взаємодія // Теорія та практика державного управління і місцевого самоврядування : електрон. наук. фах. вид. ХНТУ. - 2017. - № 1 Режим доступу : http://el-zbirn-du.at.ua/2017_1/7.pdf

\section{References:}

1. Pro privatnu detektivnu (rozshukovu) dijal'nist': proektu Zakonu Ukraïni vid 28.12.2015r № 3726.Rezhim dostupu: http://w1.c1.rada.gov.ua/pls/zweb2/webproc4_1?pf3511=57580

2. Pro privatnu detektivnu dijal'nist': proekt Zakonu Ukraïni vid 04.02.2020 № 3010. Rezhim dostupu: http://w1.c1.rada.gov.ua/pls/zweb2/webproc4_1?pf3511=68051

3. Romanenko E. O., Chaplaj I. V. Zabezpechennja rozbudovi gromadjans'kogo potencialu v Ukraïni//Ekspert: paradigmi juridichnih nauk i derzhavnogo upravlinnja: elektronne naukove vidannja: zbirnik. — 2018. — № 2 (2) — gruden'. — Kiïv : DP "Vidavnichij dim "Personal”, 2018. — s. 87-93. 
4. Diegtiar O.A., Nepomnyashchyy O. M. Transformatsiya v umovakh hlobalizatsiyi funktsiyi instytutu derzhavy, hromadyans'koho suspil'stva ta yikh vzayemodiyi // Teoriya ta praktyka derzhavnoho upravlinnya ta mistsevoho samovryaduvannya: elektron. nauk. fakh. vyd. KHNTU. 2017. - № 1. URL: http://el-zbirn-du.at.ua/2017_1/7.pdf 